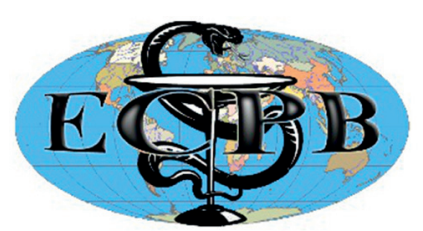

“ЕКСПЕРИМЕНТАЛЬНА ТА КЛІНІЧНА ФІЗІОЛОГІЯ І БІОХІМІЯ” "EXPERIMENTAL AND CLINICAL PHYSIOLOGY AND BIOCHEMISTRY" Науково-практичний журнал/Scientific-practical journal

Наукові статті / Research Articles

ECPB 2019, 4(88): 5-15. https://doi.org/

\title{
Predictors of individual immune responses to adaptogens
}

\author{
O.I. MEL'NYK', Z.D. STRUK ${ }^{2}$ \\ ${ }^{1}$ Danylo Halyts'kyı̌ National Medical University, L'viv, Ukraine \\ ${ }^{2}$ Ukrainian Scientific Research Institute of Medicine for Transport, Odesa, Ukraine \\ E-mail: omelnyk7@gmail.com
}

Introduction. Earlier in the experiments in rats [1,2] and in clinical observations [3-5] showed that the immune responses to chronic stress are ambiguous and individual. Adaptogens, in particular balneofactors, are antipodes of stressors [6]. The immune responses to balneotherapy are also ambiguous [7-19] which is a separate manifestation of the multivariate effects of balneological agents on the body $[20,21]$. Therefore, the purpose of this study is to analyze variants of immune responses to balneofactors of Truskavets' spa as natural adaptogens and to determine the possibility of their prediction.

Material and methods. The object of observation were 34 men and 10 women aged 24-70 years old, who came to the Truskavets' spa for the treatment of chronic pyelonephritis combined with cholecystitis in remission. The survey was conducted twice, before and after balneotherapy (drinking bioactive water Naftussya three times a day, ozokerite applications, mineral baths every other day for 7-10 days).

Immune status evaluated on a set of I and II levels recommended by the WHO as described in the manuals [22,23]. For phenotyping subpopulations of lymphocytes used the methods of rosette formation with sheep erythrocytes on which adsorbed monoclonal antibodies against receptors CD3, CD4, CD8, CD22 and CD56 from company «Granum» (Kharkiv) with visualization under light microscope with immersion system. Subpopulation of T cells with receptors high affinity determined by test of "active" rosette formation. The state of humoral immunity judged by the concentration in serum of Circulating Immune Complexes (by polyethylene glycol precipitation method) and Immunoglobulins classes M, G, A as well as in saliva of IgG, IgA, secretory IgA and Lysozyme (ELISA, analyser "Immunochem", USA).

Parameters of phagocytic function of neutrophils estimated as described by SD.

Douglas and PG Quie [24] with moderately modification by MM Kovbasnyuk [25]. The objects of phagocytosis served daily cultures of Staphylococcus aureus (ATCC N 25423 F49) as typical specimen for Gram-positive Bacteria and Escherichia coli (O55 K59) as typical representative of Gram-negative Bacteria. Both cultures obtained from Laboratory of Hydro-Geological Regime-Operational Station JSC "Truskavets'kurort". Take into account the following parameters of Phagocytosis: activity (percentage of neutrophils, in which found microbes Hamburger's Phagocytic Index PhI), intensity (number of microbes absorbed one phagocytes - Microbial Count MC or Right's Index) and completeness 
(percentage of dead microbes - Killing Index KI). On the basis of the recorded partial parameters of Phagocytosis, taking into account the Neutrophils (N) content of $1 \mathrm{~L}$ blood, we calculated the integral parameter - Bactericidal Capacity of Neutrophils (BCCN) by the formula [6]:

BCCN $\left(10^{9}\right.$ Bact/L) $=$ N $\left(10^{9} / \mathrm{L}\right) \cdot \mathrm{PhI}(\%) \cdot \mathrm{MC}($ Bact/Phag $) \cdot \mathrm{KI}(\%) \cdot 10^{-4}$

In portion of capillary blood we counted up Leukocytogram (LCG) (Eosinophils, Stub and Segmentonucleary Neutrophils, Lymphocytes and Monocytes) and calculated two variants of Adaptation Index as well as two variants of Strain Index by IL Popovych [26,27].

Strain Index-1 $=\left[(\mathrm{Eo} / 3,5-1)^{2}+(\mathrm{SN} / 3,5-1)^{2}+(\mathrm{Mon} / 5,5-1)^{2}+(\mathrm{Leu} / 6-1)^{2}\right] / 4$

Strain Index-2 $=\left[(\mathrm{Eo} / 2,75-1)^{2}+(\mathrm{SN} / 4,25-1)^{2}+(\mathrm{Mon} / 6-1)^{2}+(\mathrm{Leu} / 5-1)^{2}\right] / 4$

We calculated also the Entropy (h) of Immunocytogram (ICG) and Leukocytogram (LCG) using classical CE Shannon's formula [28-31]:

$\mathrm{hICG}=-\left[\mathrm{CD} 4 \cdot \log _{2} \mathrm{CD} 4+\mathrm{CD} 8 \cdot \log _{2} \mathrm{CD} 8+\mathrm{CD} 22 \cdot \log _{2} \mathrm{CD} 22+\mathrm{CD} 56 \cdot \log _{2}\right.$ CD56] $/ \log _{2} 4$

$\mathrm{hLCG}=-\left[\mathrm{L} \cdot \log _{2} \mathrm{~L}+\mathrm{M} \cdot \log _{2} \mathrm{M}+\mathrm{E} \cdot \log _{2} \mathrm{E}+\mathrm{SNN} \cdot \log _{2} \mathrm{SNN}+\mathrm{StubN} \cdot \log _{2}\right.$ StubN]/ $\log _{2} 5$

The condition of microbiota is evaluated on the results of sowing of feces and urine.

Norms are borrowed from the database of the Truskavets' Scientific School of Balneology [10,25].

Results processed by methods of cluster [32] and discriminant [33] analyses, using the software package "Statistica 5.5».

Results and discussion. In order to evaluate the immune responses on a single scale according recommendation by IL Popovych $[2,6]$ immune variables (V) expressed as Z-scores calculated by formula:

$\mathrm{Z}=(\mathrm{V} / \mathrm{N}-1) / \mathrm{Cv}$, where

$\mathrm{N}$ is Mean of Normal Variable,

$\mathrm{Cv}$ is Coefficient its variation.

Eleven key immune parameters were used to calculate the Immune Status Index (ISI) by the formula:

ISI=(BCCN St. aur.+BCCN E. coli+CIC+IgM+IgG+IgA+B+NK+Th+Tc+Ta)/11.

Preliminary analysis has shown that in different patients, individual ISI respond to balneotherapy not only in varying degrees, but even in the opposite way. The next phase was conducted Cluster analysis of ISI before and after balneotherapy. Clustering cohort of persons is realized by iterative k-means metod. In this method, the object belongs to the class Euclidean distance to which is minimal. The main principle of the structural approach to the allocation of uniform groups consists in the fact that objects of same class are close but different classes are distant [32].

As a result, four groups of persons were created, significantly different from each other in terms of ISI (Table 1 and Fig. 1).

Table 1.

Average values (Mean \pm SE) of immune status index (ISI) before and after balneotherapy in members of different clusters

\begin{tabular}{|c|c|c|c|c|}
\hline & Cluster & Cluster & Cluster & Cluster \\
\hline & No.1(2) & No.2(14) & No.3(18) & No.4(10) \\
\hline ISI before & $+0,60 \pm 0,50$ & $-0,55 \pm 0,05$ & $+0,23 \pm 0,06$ & $-0,87 \pm 0,13$ \\
\hline ISI after & $-0,95 \pm 0,16$ & $+0,22 \pm 0,08$ & $+0,35 \pm 0,07$ & $-0,68 \pm 0,10$ \\
\hline
\end{tabular}

Cluster №3 (40,9\% of the sample), whose members are characterized by a stable normal (N) immune status, appeared to be the largest, which is quite expected given the remission phase of the chronic inflammatory process. In 
members of cluster №2 (31,8\%), the lower boundary level of immunity (N-) was completely normalized $(\mathrm{N})$, indicating a favorable immunotropic effect of balneotherapy.

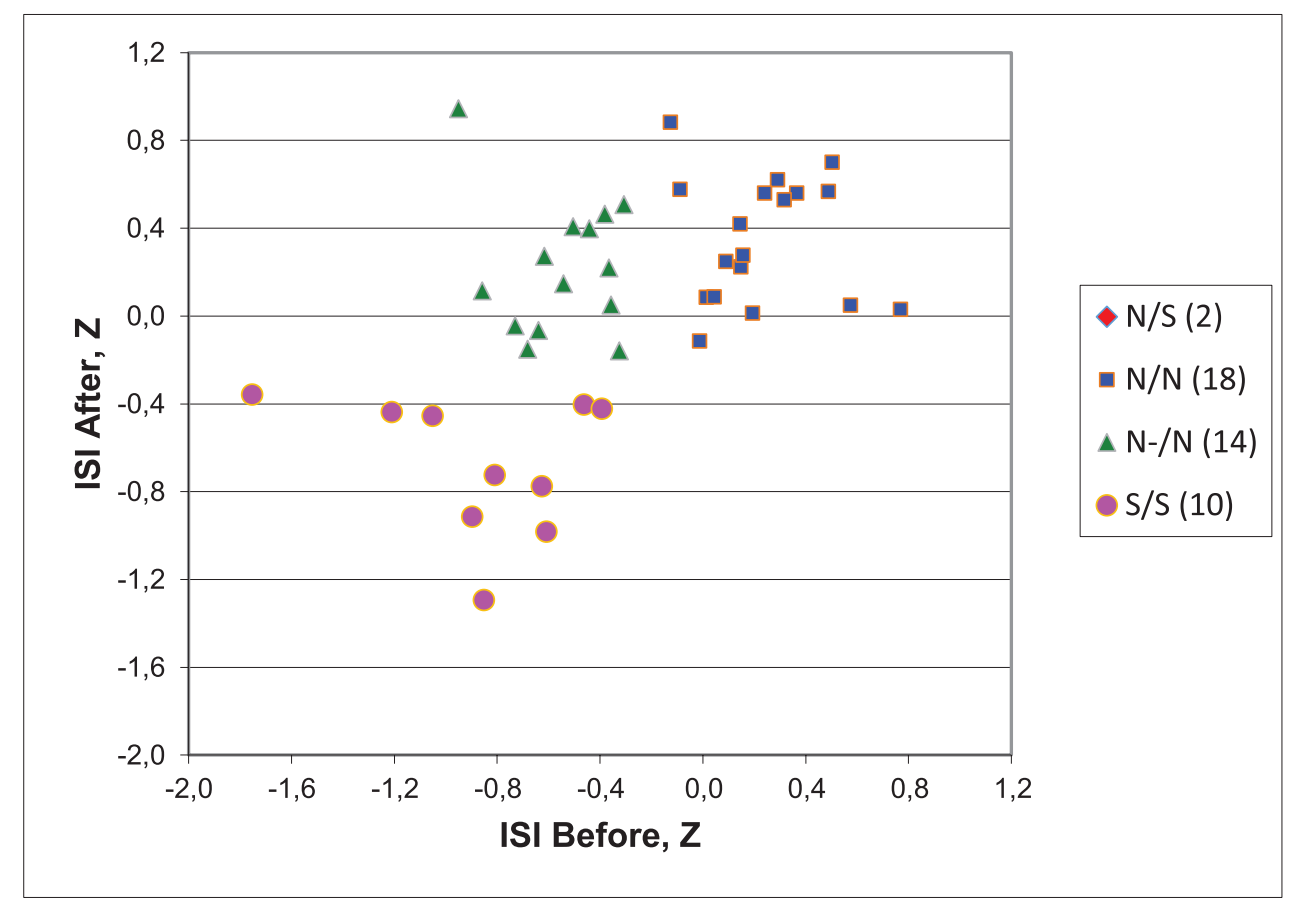

Fig. 1. Individual immune status indexes (ISI) before (axis X) and after (axis Y) balneotherapy in members of different clusters of immune responses

In members of cluster №4 (22,7\%), moderate immunosuppression (S) was reduced but not sufficient. However, in two patients of cluster №1 $(4,5 \%)$, initially normal immune status $(\mathrm{N})$ was transformed into moderate immunosuppression (S). Therefore, the immunotropic effect of balneotherapy on certain individuals is not effective enough, and in some cases even unfavorable.

In order to determine the possibility of predicting the nature of the immune response to balneotherapy on the basis of the initial parameters we have used discriminant analysis. The forward stepwise program included 20 predictors in the model, including 12 immune blood parameters and one saliva parameter, 4 information parameters, 2 fecal microbiota parameters as well as erythrocyturia (Tables 2 and 3 ).

Table 2 .

Discriminant Function Analysis Summary

for Variables predicting various Immune responses

Step 20, $\mathrm{N}$ of vars in model: 20; Grouping: 4 grps; Wilks' $\Lambda$ : 0,0012; approx. $\mathrm{F}_{(60,6)}=9,15 ; \mathrm{p}<10^{-6}$

\begin{tabular}{|l|c|c|c|c|c|}
\hline \multicolumn{1}{|c|}{$\begin{array}{c}\text { Variables } \\
\text { currently in the model }\end{array}$} & $\begin{array}{c}\text { Wilks' } \\
\Lambda\end{array}$ & $\begin{array}{c}\text { Partial } \\
\Lambda\end{array}$ & $\begin{array}{c}\text { F-remo- } \\
\text { ve (3,2) }\end{array}$ & $\begin{array}{c}\mathbf{p}- \\
\text { level }\end{array}$ & $\begin{array}{c}\text { Tole- } \\
\text { rancy }\end{array}$ \\
\hline IgA Serum, g/L &, 0016 &, 711 & 2,85 &, 062 &, 396 \\
\hline Bactericidity vs Staph. aur, 10 ${ }^{9}$ Bacteria/L &, 0016 &, 720 & 2,73 &, 070 &, 125 \\
\hline $\begin{array}{l}\text { Popovych's Leukocytary Strain Index-1, } \\
\text { pts }\end{array}$ &, 0044 &, 264 & 19,5 & $10^{-5}$ &, 029 \\
\hline Lysozime Saliva, mg/L &, 0058 &, 198 & 28,3 & $10^{-6}$ &, 079 \\
\hline
\end{tabular}




\begin{tabular}{|c|c|c|c|c|c|}
\hline $\begin{array}{c}\text { Variables } \\
\text { currently in the model } \\
\end{array}$ & $\underset{\Lambda}{\text { Wilks' }}$ & $\begin{array}{c}\text { Partial } \\
\Lambda\end{array}$ & $\begin{array}{l}\text { F-remo- } \\
\text { ve }(3,2)\end{array}$ & $\begin{array}{c}\text { p- } \\
\text { level }\end{array}$ & $\begin{array}{l}\text { Tole- } \\
\text { rancy }\end{array}$ \\
\hline $\begin{array}{l}\text { Microbial Count vs Staph. aur, Bact/ } \\
\text { Phagoc. }\end{array}$ & ,0014 &, 813 & 1,61 & ,217 & 200 \\
\hline 0-Lymphocytes of Blood, \% & ,0019 & ,621 & 4,28 & 017 & ,211 \\
\hline Stub Neutrophiles of Blood, \% & ,0017 & ,683 & 3,24 &, 043 & ,409 \\
\hline IgG Serum, g/L &, 0025 & ,468 & 7,96 & 001 & ,335 \\
\hline E. coli faeces, $10^{6} \mathrm{CFU} / \mathrm{g}$ & 0015 & ,748 & 2,36 & 101 & 165 \\
\hline $\begin{array}{l}\text { Microbial Count vs E. coli, Bacter/ } \\
\text { Phagocyte }\end{array}$ & ,0035 & ,330 & 14,2 & $10^{-4}$ & ,047 \\
\hline Bactericidity vs E. coli, $10^{9}$ Bacteria/L & ,0023 &, 511 & 6,71 & ,002 & 066 \\
\hline Entropy of Immunocytogram & ,0017 & ,688 & 3,18 &, 045 & ,294 \\
\hline $\begin{array}{l}\text { Popovych's Leukocytary Adaptation } \\
\text { Ind-1, pts }\end{array}$ & ,0016 & ,742 & 2,44 & ,093 & ,263 \\
\hline CD3 $^{+}$T-active Lymphocytes, $\%$ &, 0020 & ,564 & 5,40 & ,006 & ,407 \\
\hline $\begin{array}{l}\text { Popovych's Leukocytary Strain Index-2, } \\
\text { pts }\end{array}$ & ,0019 & ,621 & 4,28 & ,017 & ,048 \\
\hline Pan-Lymphocytes of Blood, \% & ,0017 & ,673 & 3,40 & ,037 & ,222 \\
\hline Erhytrocyturia, lg/L &, 0017 & ,689 & 3,15 & ,046 & ,339 \\
\hline $\mathrm{CD}^{+} \mathrm{CD}^{+}$T-cytolytic Lymphocytes, \% & ,0016 &, 731 & 2,58 & 081 & ,416 \\
\hline Lactobacillus faeces, lg CFU/g &, 0015 & ,789 & 1,87 & , 166 &, 189 \\
\hline $\begin{array}{l}\text { Phagocytose Index vs Staphylococcus } \\
\text { aur, \% }\end{array}$ & ,0013 & ,856 & 1,18 & ,342 & ,268 \\
\hline
\end{tabular}

Table 3 .

Summary of Stepwise Analysis for Variables predicting various Immune responses. The variables are ranked by criterion Lambda

\begin{tabular}{|c|c|c|c|c|c|}
\hline $\begin{array}{c}\text { Variables } \\
\text { currently in the model }\end{array}$ & $\begin{array}{l}\text { F to } \\
\text { enter }\end{array}$ & p-level & $\Lambda$ & $\begin{array}{c}\text { F- } \\
\text { value }\end{array}$ & $\begin{array}{c}\text { p- } \\
\text { level }\end{array}$ \\
\hline IgA Serum, g/L & 12,0 & $10^{-5}$ &, 527 & 12,0 & $10^{-5}$ \\
\hline Bactericidity vs Staph. aur, $10^{9}$ Bacteria/L & 10,9 & $10^{-4}$ & ,287 & 11,3 & $10^{-6}$ \\
\hline Popovych's Leukocytary Strain Index-1, pts & 6,3 & ,001 & ,192 & 10,0 & $10^{-6}$ \\
\hline Lysozime Saliva, mg/L & 7,2 & 001 & 121 & 10,0 & $10^{-6}$ \\
\hline Microbial Count vs Staph. aur, Bact/Phagoc. & 6,2 & ,002 &, 080 & 10,0 & $10^{-6}$ \\
\hline 0-Lymphocytes of Blood, \% & 5,2 &, 005 &, 055 & 9,8 & $10^{-6}$ \\
\hline Stub Neutrophiles of Blood, \% & 4,0 & 016 & 041 & 9,5 & $10^{-6}$ \\
\hline IgG Serum, g/L & 3,2 & 036 & 032 & 9,2 & $10^{-6}$ \\
\hline E. coli faeces, $10^{6} \mathrm{CFU} / \mathrm{g}$ & 3,8 &, 020 & 024 & 9,1 & $10^{-6}$ \\
\hline Microbial Count vs E. coli, Bacter/Phagocyte & 2,8 &, 059 & ,019 & 8,8 & $10^{-6}$ \\
\hline Bactericidity vs E. coli, $10^{9}$ Bacteria/L & 3,1 & 039 & 014 & 8,8 & $10^{-6}$ \\
\hline Entropy of Immunocytogram & 4,0 & 017 & 010 & 9,0 & $10^{-6}$ \\
\hline Popovych's Leukocytary Adaptation Ind-1, pts & 3,5 &, 027 &, 007 & 9,2 & $10^{-6}$ \\
\hline CD3 $^{+}$T-active Lymphocytes, \% & 4,4 & 013 & 005 & 9,6 & $10^{-6}$ \\
\hline Popovych's Leukocytary Strain Index-2, pts & 2,4 & 093 &, 004 & 9,5 & $10^{-6}$ \\
\hline Pan-Lymphocytes of Blood, \% & 2,9 & 057 & 003 & 9,7 & $10^{-6}$ \\
\hline Erhytrocyturia, lg/L & 3,0 & 049 & ,002 & 9,9 & $10^{-6}$ \\
\hline $\mathrm{CD}^{+}{ }^{+} \mathrm{CD}^{+}$T-cytolytic Lymphocytes, \% & 1,6 & ,218 & 002 & 9,6 & $10^{-6}$ \\
\hline Lactobacillus faeces, lg CFU/g & 2,0 &, 146 & 001 & 9,5 & $10^{-6}$ \\
\hline Phagocytose Index vs Staphylococcus aur, \% & 1,2 & ,342 & 001 & 9,2 & $10^{-6}$ \\
\hline
\end{tabular}

Next, the 20-dimensional space of discriminant variables transforms into 3 -dimensional space of canonical roots, which are a linear combination of dis- 
criminant variables. The canonical correlation coefficient is for Root 10,983 (Wilks' $\Lambda=0,0012 ; \chi_{(60)}^{2}=210 ; p<10^{-6}$ ), for Root 20,943 (Wilks' $\Lambda=0,0337 ; \chi_{(38)}^{2}=105$; $p<10^{-6}$ ) and for Root 30,834 (Wilks' $\Lambda=0,3039 ; \chi^{2}{ }_{(18}=37 ; p=0,005$ ). The major root contains $73,1 \%$ of discriminative properties, the second $20,9 \%$ and the minor $6,0 \%$.

Table 4 presents standardized (normalized) and raw (actual) coefficients for discriminant variables. The calculation of the discriminant root values for each person as the sum of the products of raw coefficients to the individual values of discriminant variables together with the constant enables the visualization of each patient in the information space of the roots.

Table 4.

Standardized and Raw Coefficients and Constants for predicting Variables

\begin{tabular}{|l|c|c|c|c|c|c|}
\hline & \multicolumn{3}{|c|}{ Standardized } & \multicolumn{3}{c|}{ Raw } \\
\hline & Root 1 & Root 2 & Root 3 & Root 1 & Root 2 & Root 3 \\
\hline IgA Serum, g/L &, 678 &,- 189 &, 605 & 1,719 &,- 478 & 1,533 \\
\hline $\begin{array}{l}\text { Bactericidity vs Staph. aur, } \\
\text { 109 Bacteria/L }\end{array}$ & $-1,329$ &, 243 &,- 840 &,- 077 &, 014 &,- 049 \\
\hline $\begin{array}{l}\text { Popovych's Leukocytary } \\
\text { Strain Index-1, pts }\end{array}$ & $-5,080$ &,- 276 &, 554 & $-15,04$ &,- 818 & 1,641 \\
\hline Lysozime Saliva, mg/L & 3,190 &,- 633 &, 147 &, 589 &,- 117 &, 027 \\
\hline $\begin{array}{l}\text { Microbial Count vs Staph. } \\
\text { aur, Bact/Phagoc. }\end{array}$ &, 578 &,- 400 &, 823 &, 089 &,- 061 &, 126 \\
\hline 0-Lymphocytes of Blood, \% &, 482 & 1,222 &, 591 &, 099 &, 251 &, 121 \\
\hline $\begin{array}{l}\text { Stub Neutrophiles of } \\
\text { Blood, \% }\end{array}$ &,- 841 &, 165 &,- 310 &,- 819 &, 160 &,- 302 \\
\hline IgG Serum, g/L &, 823 &,- 530 &,- 991 &, 257 &,- 166 &,- 309 \\
\hline E. coli faeces, 106 CFU/g &,- 023 &,- 354 & $-1,426$ &,- 0002 &,- 0030 &,- 0121 \\
\hline $\begin{array}{l}\text { Microbial Count vs E. coli, } \\
\text { Bacter/Phagocyte }\end{array}$ & $-3,515$ &, 783 & $-1,635$ &,- 494 &, 110 &,- 230 \\
\hline $\begin{array}{l}\text { Bactericidity vs E. coli, 10 } \\
\text { Bacteria/L }\end{array}$ & 2,073 & $-1,719$ &, 992 &, 096 &,- 080 &, 046 \\
\hline Entropy of Immunocytogram &, 580 &, 435 &, 904 & 22,14 & 16,58 & 34,46 \\
\hline $\begin{array}{l}\text { Popovych's Leukocyt } \\
\text { Adaptation Ind-1, pts }\end{array}$ &,- 622 &,- 825 &,- 063 & $-1,148$ & $-1,522$ &,- 116 \\
\hline $\begin{array}{l}\text { CD3+ T-active } \\
\text { Lymphocytes, \% }\end{array}$ &,- 970 &,- 293 &,- 349 &,- 193 &,- 058 &,- 069 \\
\hline $\begin{array}{l}\text { Popovych's Leukocytary } \\
\text { Strain Index-2, pts }\end{array}$ & 2,827 &, 356 &,- 236 & 5,700 &, 717 &,- 476 \\
\hline Pan-Lymphocytes of Blood, \% & $-1,064$ &, 620 &,- 233 &,- 167 &, 097 &,- 037 \\
\hline Erhytrocyturia, lg/L &,- 772 &, 575 &,- 262 & $-2,645$ & 1,971 &,- 899 \\
\hline $\begin{array}{l}\text { CD8+CD3 T-cytolytic } \\
\text { Lymphocytes, \% }\end{array}$ &, 799 &,- 014 &,- 209 &, 174 &,- 003 &,- 046 \\
\hline $\begin{array}{l}\text { Lactobacillus faeces, lg } \\
\text { CFU/g }\end{array}$ &,- 751 &, 302 &,- 839 &,- 574 &, 231 &,- 641 \\
\hline $\begin{array}{l}\text { Phagocytose Index vs } \\
\text { Staphylococcus aur, \% }\end{array}$ &,- 453 &,- 231 &, 646 &,- 424 &,- 215 &, 604 \\
\hline & & Constants & $-37,96$ & 23,06 & $-75,10$ \\
\hline & & Cum. Prop. &, 732 &, 940 & 1,000 \\
\hline
\end{tabular}

Extreme localization along the axis of the first root (Fig. 2) of members of the N/S cluster reflects their maximally increased Popovych's Strain Index-1, Entropy of Immunocytogram, the Intensity of phagocytosis and Bactericidity of neutrophils against both groups of bacteria, on the one hand, and minimal 
Popovych's Adaptation Index-1, maximum Lysozyme deficiency in saliva and IgG in serum in combination with the minimum for the sample increased levels of IgA in it (table. 5). The members of other clusters do not differ in the totality of the predictors listed (mixed along the axis of the first root). Instead, the members of the $\mathrm{N} / \mathrm{N}$ cluster are clearly distinguished along the axis of the second root, while the $\mathrm{S} / \mathrm{S}$ and $\mathrm{N}-/ \mathrm{N}$ clusters are mixed. Delimitation of the latter occurs along the axis of the third root (Fig. 3).

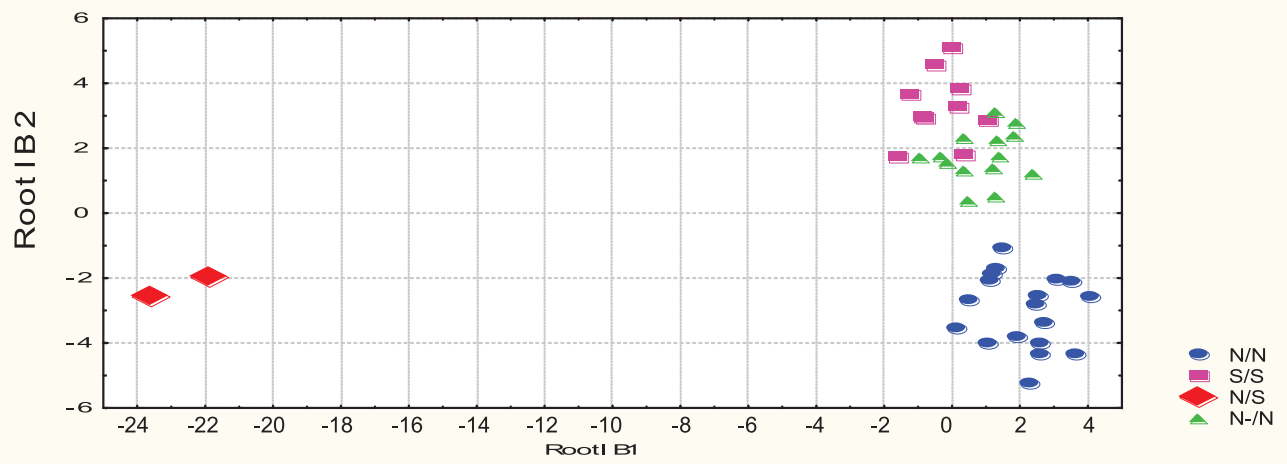

Fig. 2. Individual values of the first and second roots in which condensed the information about predictors of various immune responses

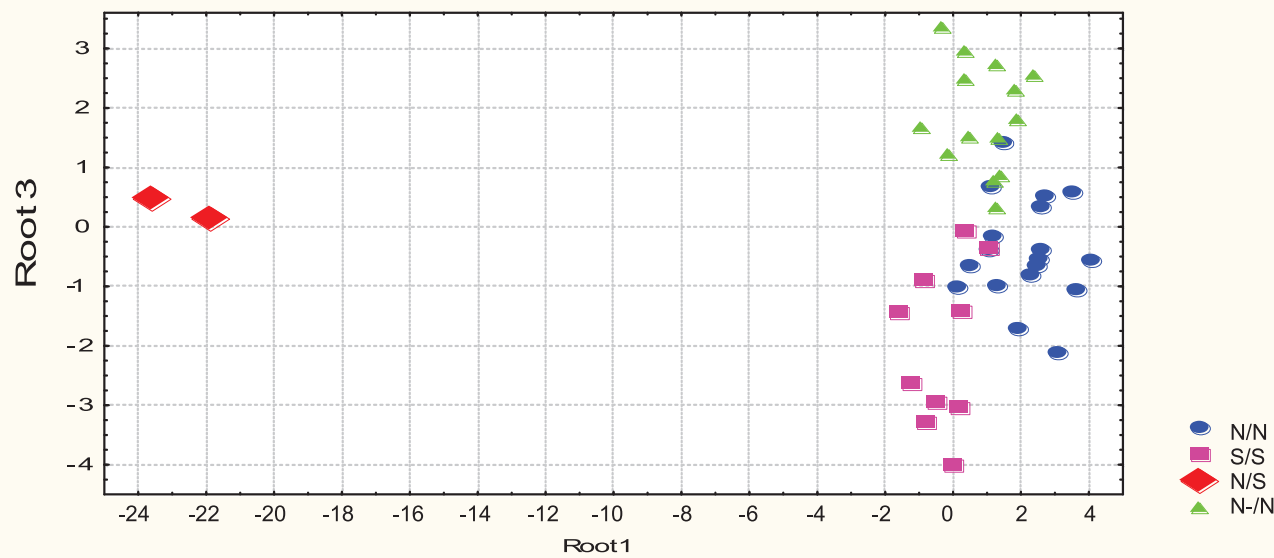

Fig. 3. Individual values of the first and third roots in which condensed the information about predictors of various immune responses

Table 5 .

Correlations Variables-Canonical Roots, Means of Roots and predicting Variables for Clusters of immune responses

\begin{tabular}{|l|l|l|l|l|l|l|l|l|}
\hline & \multicolumn{3}{|c|}{ Correlations Variables- } & \multicolumn{1}{|c|}{$\begin{array}{c}\text { N/S } \\
\text { Roots }\end{array}$} & $\begin{array}{c}\text { S/S } \\
(10)\end{array}$ & $\begin{array}{c}\text { N-/N } \\
(\mathbf{1 4})\end{array}$ & $\begin{array}{c}\text { N/N } \\
(\mathbf{1 8})\end{array}$ & $\begin{array}{c}\text { Norm } \\
\mathbf{( 3 0 )}\end{array}$ \\
\hline Root 1 (73,1\%) & R1 & R2 & R3 & $-22,8$ & $-0,36$ & $+0,85$ & $+2,07$ & \\
\hline $\begin{array}{l}\text { Popovych's Leukocy- } \\
\text { tary Strain Index-1, } \\
\text { pts }\end{array}$ &,- 129 &,- 006 &, 106 & $\mathbf{0 , 2 1 5}$ & 0,141 & 0,203 & 0,127 & 0,067 \\
\hline $\begin{array}{l}\text { Bactericidity vs E. } \\
\text { coli, 109 Bacteria/L }\end{array}$ &,- 109 &,- 235 &, 041 & $\mathbf{1 5 4}$ & 71 & 80 & 99 & 99 \\
\hline $\begin{array}{l}\text { Bactericidity vS } \\
\text { Staph. aur, 109 Bac- } \\
\text { teria/L }\end{array}$ &,- 078 &,- 222 &, 095 & $\mathbf{1 3 0}$ & 75 & 85 & 98 & 106 \\
\hline
\end{tabular}




\begin{tabular}{|c|c|c|c|c|c|c|c|c|}
\hline \multirow{2}{*}{\begin{tabular}{|l|}
$\begin{array}{l}\text { Entropy of Immuno- } \\
\text { cytogram }\end{array}$ \\
\end{tabular}} & \multicolumn{3}{|c|}{$\begin{array}{l}\text { Correlations Variables- } \\
\text { Roots }\end{array}$} & \multirow{2}{*}{$\begin{array}{c}\begin{array}{c}N / S \\
(2)\end{array} \\
0,995\end{array}$} & \multirow{2}{*}{\begin{tabular}{|r|}
$\begin{array}{r}\text { S/S } \\
(10)\end{array}$ \\
0,956 \\
\end{tabular}} & \multirow{2}{*}{\begin{tabular}{|c|}
$\mathbf{N}-/ \mathbf{N}$ \\
$(14)$ \\
0,970 \\
\end{tabular}} & \multirow{2}{*}{\begin{tabular}{|r|}
$\mathbf{N} / \mathbf{N}$ \\
$(18)$ \\
0,957
\end{tabular}} & \multirow{2}{*}{$\begin{array}{c}\begin{array}{c}\text { Norm } \\
(30)\end{array} \\
0,960\end{array}$} \\
\hline &,- 054 & ,017 &, 158 & & & & & \\
\hline $\begin{array}{l}\text { Microbial Count vs } \\
\text { E. coli, Bacter/Phago- } \\
\text { cyte }\end{array}$ &,- 034 &, 052 & ,167 & 70 & 64 & 67 & 62 & 55 \\
\hline $\begin{array}{l}\text { Microbial Count vs } \\
\text { Staph. aur, Bact/ } \\
\text { Phagoc. }\end{array}$ &,- 029 & ,071 &, 194 & 66 & 61 & 65 & 60 & 61,6 \\
\hline $\begin{array}{l}\text { Lysozime Saliva, } \\
\text { mg/L }\end{array}$ &, 121 &, 121 &, 074 & 154 & 172 & 173 & 169 & 180 \\
\hline IgG Serum, g/L &, 077 &,- 131 &,- 272 & 9,4 & 14,6 & 12,2 & 16,5 & 12,75 \\
\hline IgA Serum, g/L &, 075 &,- 284 & ,202 & 1,20 & 1,41 & 1,44 & 1,48 & 1,15 \\
\hline $\begin{array}{l}\text { Popovych's Leukocyt } \\
\text { Adaptation Ind-1, pts }\end{array}$ &, 048 &,- 126 &,- 013 & 0,62 & 0,84 & 0,95 & 1,32 & 1,70 \\
\hline Root $2(20,9 \%)$ & & & & $-2,22$ & $+3,31$ & $+1,76$ & $-2,96$ & \\
\hline $\begin{array}{l}\text { CD3 }^{+} \text {T-active Lym- } \\
\text { phocytes, \% }\end{array}$ &,- 026 &,- 099 &, 024 & 33,0 & 27,0 & 28,1 & 30,0 & 30,0 \\
\hline $\begin{array}{l}\text { Phagocytose Index } \\
\text { vs Staphylococcus } \\
\text { aur, \% }\end{array}$ &,- 001 &,- 090 & ,036 & 99,0 & 98,3 & 98,6 & 99,0 & 98,3 \\
\hline $\begin{array}{l}\text { CD8 }^{+} \text {CD }^{+}{ }^{+} \text {T-cytolytic } \\
\text { Lymphocytes, \% }\end{array}$ &,- 018 &,- 077 &,- 006 & 25,5 & 21,8 & 22,1 & 23,8 & 23,5 \\
\hline $\begin{array}{l}\text { 0-Lymphocytes of } \\
\text { Blood, \% }\end{array}$ &, 041 &, 242 &,- 077 & $-4,3$ & 7,6 & 4,6 & 0,1 & 0 \\
\hline $\begin{array}{l}\text { Pan-Lymphocytes of } \\
\text { Blood, \% }\end{array}$ &,- 046 &, 209 &,- 144 & 37,3 & 40,3 & 34,3 & 29,7 & 32,0 \\
\hline Root $3(6,0 \%)$ & & & & $+0,33$ & $-1,99$ & $+1,88$ & $-0,39$ & \\
\hline $\begin{array}{l}\text { Lactobacillus faeces, } \\
\lg \text { CFU/g }\end{array}$ &,- 039 &,- 056 &,- 239 & 7,04 & 6,21 & 5,05 & 6,04 & 8,10 \\
\hline $\begin{array}{l}\text { E. coli faeces, } 10^{6} \\
\text { CFU/g }\end{array}$ &,- 036 &, 047 &,- 236 & 269 & 268 & 147 & 178 & 455 \\
\hline $\begin{array}{l}\text { Stub Neutrophiles of } \\
\text { Blood, \% }\end{array}$ & ,005 &,- 128 &,- 209 & 2,63 & 2,51 & 1,89 & 3,00 & 4,25 \\
\hline $\begin{array}{l}\text { Popovych's Leukocy- } \\
\text { tary Strain Index-2, } \\
\text { pts }\end{array}$ &,- 017 &, 026 &, 156 & 0,261 & 0,199 & 0,302 & 0,179 & 0,065 \\
\hline Erhytrocyturia, lg/L &,- 004 & 081 & ,088 & 3,00 & 3,07 & 3,13 & 2,96 & 2,70 \\
\hline
\end{tabular}

In general, predictors of all four clusters of immune responses on the planes of the discriminant roots are quite clearly delineated, which is documented by calculating the Mahalanobis distances (Table 6).

Squared Mahalanobis Distances between Clusters, F-values $(\mathrm{df}=\mathbf{2 0 , 2})$ and $\mathrm{p}$-levels

\begin{tabular}{|c|c|c|c|c|}
\hline Clusters & $\mathrm{N} / \mathrm{N}$ & $\mathrm{S} / \mathrm{S}$ & $\mathrm{N} / \mathrm{S}$ & $\mathrm{N}-/ \mathrm{N}$ \\
\hline $\mathrm{N} / \mathrm{N}$ & 0 & 53 & 679 & 32 \\
\hline $\mathrm{S} / \mathrm{S}$ & $\begin{array}{l}8,1 \\
10^{-5}\end{array}$ & 0 & 592 & 21 \\
\hline $\mathrm{N} / \mathrm{S}$ & $\begin{array}{l}16,8 \\
10^{-6}\end{array}$ & $\begin{array}{c}14,0 \\
10^{-6}\end{array}$ & 0 & 634 \\
\hline $\mathrm{N}-/ \mathrm{N}$ & $\begin{array}{l}6,2 \\
10^{-4}\end{array}$ & $\begin{array}{c}\mathbf{2 , 9} \\
0,010\end{array}$ & $\begin{array}{c}15,4 \\
10^{-6}\end{array}$ & 0 \\
\hline
\end{tabular}


Predicting the nature of the immune response is realized with the help of classifying functions (Table 7). These functions are special linear combinations that maximize differences between groups and minimize dispersion within groups. An object belongs to a group with the maximum value of a function calculated by summing the products of the values of the variables by the coefficients of the classifying functions plus the constant.

Table 7 .

\section{Coefficients and Constants for Classification Functions} of Clusters of Immune responses

\begin{tabular}{|l|c|c|c|c|}
\hline \multicolumn{1}{|c|}{ Clusters } & N/N & S/S & N/S & N-/N \\
\hline Variables & $\mathrm{p}=, 409$ & $\mathrm{p}=, 227$ & $\mathrm{p}=, 045$ & $\mathrm{p}=, 318$ \\
\hline IgA Serum, g/L & $-22,98$ & $-32,60$ & $-64,91$ & $-23,85$ \\
\hline $\begin{array}{l}\text { Bactericidity vs Staph. aur, 10 } \\
\text { Bacteria/L }\end{array}$ & $-6,20$ & $-5,85$ & $-4,31$ & $-6,15$ \\
\hline $\begin{array}{l}\text { Popovych's Leukocytary Strain Index-1, } \\
\text { pts }\end{array}$ & $-150,0$ & $-121,20$ & 224,1 & $-131,9$ \\
\hline Lysozime Saliva, mg/L & 37,15 & 34,94 & 22,46 & 35,95 \\
\hline $\begin{array}{l}\text { Microbial Count vs Staph. aur, Bact/ } \\
\text { Phagoc. }\end{array}$ & 5,39 & 4,59 & 3,24 & 5,28 \\
\hline 0-Lymphocytes of Blood, \% & 18,85 & 19,99 & 16,67 & 20,19 \\
\hline Stub Neutrophiles of Blood, \% & $-36,24$ & $-32,77$ & $-16,01$ & $-35,18$ \\
\hline IgG Serum, g/L & $-14,60$ & $-15,77$ & $-21,33$ & $-16,40$ \\
\hline E. coli faeces, 10 CFU/g & $-1,64$ & $-1,64$ & $-1,64$ & $-1,68$ \\
\hline $\begin{array}{l}\text { Microbial Count vs E. coli, Bacter/ } \\
\text { Phagocyte }\end{array}$ & $-58,11$ & $-55,86$ & $-45,92$ & $-57,52$ \\
\hline Bactericidity vs E. coli, 109 Bacteria/L & 9,73 & 8,93 & 7,32 & 9,34 \\
\hline Entropy of Immunocytogram & 6136,8 & 6132,2 & 5624,3 & 6266,5 \\
\hline $\begin{array}{l}\text { Popovych's Leukocytary Adaptation } \\
\text { Ind-1, pts }\end{array}$ & $-93,66$ & $-100,2$ & $-66,37$ & $-99,72$ \\
\hline CD3+ T-active Lymphocytes, \% & $-15,05$ & $-14,83$ & $-10,34$ & $-15,25$ \\
\hline $\begin{array}{l}\text { Popovych's Leukocytary Strain Index-2, } \\
\text { pts }\end{array}$ & $-57,27$ & $-65,86$ & $-198,6$ & $-61,87$ \\
\hline Pan-Lymphocytes of Blood, \% & $-15,43$ & $-14,36$ & $-11,24$ & $-14,85$ \\
\hline Erhytrocyturia, lg/L & $-492,89$ & $-472,6$ & $-426,3$ & $-482,3$ \\
\hline CD8+CD3+T-cytolytic Lymphocytes, \% & $-1,82$ & $-2,19$ & $-6,17$ & $-2,15$ \\
\hline Lactobacillus faeces, lg CFU/g & $-127,0$ & $-123,1$ & $-113,0$ & $-126,6$ \\
\hline $\begin{array}{l}\text { Phagocytose Index vs Staphylococcus } \\
\text { aur, \% }\end{array}$ & 271,12 & 269,8 & 281,9 & 272,0 \\
\hline Constants & $-16014,4$ & $-15659,3$ & $-15366,2$ & $-16027,0$ \\
\hline
\end{tabular}

We can retrospectively recognize members of three clusters unmistakably, and only the cluster S/S is with one error. This means that, with the help of predictors and classification functions, the identity of a particular person to one or another cluster of immune responses is almost unmistakable.

Conclusion. Four variants of the immune responses of patients with chronic inflammatory process to adaptogenic balneotherapy have been identified. In $40,9 \%$ of patients, initially normal immune status did not change significantly. In $31,8 \%$, the lower boundary level of immunity is completely normalized. In $22,7 \%$ moderate immunosuppression is reduced, but not up to normal. However, in 4,5\% of people, initially normal level of immunity are transformed into moderate immunosuppression. All four variants of immune responses are virtually unmistakably predicted by a set of 20 predictors, which allows us to make adjustments to balneotherapy in advance. 


\section{ACKNOWLEDGMENT}

We express sincere gratitude to administration of JSC "Truskavets'kurort" and "Truskavets' SPA" as well as clinical sanatorium "Moldova" for help in conducting this investigation.

\section{ACCORDANCE TO ETHICS STANDARDS}

Tests in patients are conducted in accordance with positions of Helsinki Declaration 1975, revised and complemented in 2002, and directive of National Committee on ethics of scientific researches. During realization of tests from all participants the informed consent is got and used all measures for providing of anonymity of participants. For all authors any conflict of interests is absent.

\section{REFERENCES (ПОСИЛАННЯ)}

1. Popovych IL, Polovynko IS, Zajats LM, Mel'nyk OI. Sexual dimorphism of the neuroendocrine-immune complex and its reactions on chronic stress at rats. Experimental and Clinical Physiology and Biochemistry. 2018;3(83):5-17.

2. Gozhenko AI, Zukow W, Polovynko IS, Zajats LM, Yanchij RI, Portnichenko VI et al. Individual Immune Responses to Chronic Stress and their Neuro-Endocrine Accompaniment. RSW. UMK. Radom. Torun; 2019: 200 p.

3. Lukyanchenko OI, Gozhenko OA, Mel'nyk OI, Zukow W, Popovych IL. Features of the immune profile and microbiota in persons whose immune status is susceptible or resistant to chronic stress. Journal of Education, Health and Sport. 2019;9(3):601-11.

4. Mel'nyk OI, Lukyanchenko OI, Gozhenko OA, Popovych IL. Features of the parameters of EEG in persons whose immune status is susceptible or resistant to chronic stress. Experimental and Clinical Physiology and Biochemistry. 2019;2(86):11-23.

5. Gozhenko OA, Lukyanchenko OI, Mel'nyk OI, Zukow WA, Popovych IL. The immune profiles and microbiota in persons whose immune status is susceptible or resistant to chronic stress. In: Collection of Proceedings of the Scientific and Practical Conference: Galician Readings "Contemporary ideas on the pathogenesis of inflammation: local and systemic mechanisms» (Ivano-Frankivs'k, 19-20 September). Ivano-Frankivs'k: IFNMU; 2019:74-5.

6. Kostyuk PG, Popovych IL, Ivassivka SV (editors). Chornobyl', Adaptive and Defensive Systems, Rehabilitation [in Ukrainian]. Kyiv. Computerpress; 2006: 348 p.

7. Ivassivka SV, Bilas VR, Popovych AI. Influence applications of ozokerite on phone of chronic stress on parameters of neuro-endocrine-immune complex and hydro-electrolyte exchange at rats. Communication 1: Stresslimiting, sanogene and neutral effects [in Ukrainian]. Medical Hydrology and Rehabilitation. 2008;6(4):65-72.

8. Ivassivka SV, Bilas VR, Popovych AI. Stresslimiting effects of ozokerite on neuroendocrine-immune complex at rats. In: International Scientific Congress and 61-st Session of the General Assembly of the World Federation of Hydrotherapy Climatotherapy (FEMTEC). Congress materials. China, November 26-28, 2008:216-17.

9. Khodak OL, Bilas VR, Nazarenko NK. Variants of immunotropic and clinical effects of balneotherapy at Truskavets spa in individuals after radical treatment of oncopathology [in Ukrainian]. Medical Hydrology and Rehabilitation. 2006;4(3):9-32.

10. Kul'chyns'kyi $A B, Z$, Zkow $W$. Three variants of immune responses to balneotherapy at the spa Truskavets' in patients with chronic pyelonephritis and cholecystitis. Journal of Education, Health and Sport. 2018;8(3):476-89.

11. Popovych AI. Features of the immunotropic effects of partial components of the balneotherapeutic complex of spa Truskavets'. Journal of Education, Health and Sport. 2018;8(12):919-35.

12. Popovych IL, Gumega MD, Verba IE, Popovych AI, Korolyshyn TA, Tkachuk SP et al. Comparative investigation effects on nervous and immune systems of bioactive water Naftussya spa Truskavets' and stable water solution of Boryslav's ozokerite. Journal of Education, Health and Sport. 2016;6(4):364-74.

13. Popovych IL, Struk ZD, Vis'tak-Markevych HI, Duda NB, Korda MM. Sexual dimorphism of reactions of the neuroendocrine-immune complex and metabolism to adaptogenic balneotherapy in individuals with dysadaptosis. In: Proceedings of the XI Scientific-Practical Conference (with international participation) «Topical issues of pathology in the event of emergency factors on the body» (Ternopil, October 4-5, 2018). Ternopil, 2018:49-50.

14. Struk ZD. Relationships between neurohormonal and immunotropic effects of balneotherapy with Naftussya bioactive water [in Ukrainian]. In: Proceedings of the II ScientificPractical Conference (with international participation) «Topical issues of pathology in the event of emergency factors on the body» (Ternopil, November 5-6, 2009). Achievements of clinical and experimental medicine. 2009;2(11):140.

15. Struk ZD. Cluster analysis of immunotropic effects of Naftussya bioactive water in women with thyroid hyperplasia [in Ukrainian]. In: Bulletin of VIII readings by VV Podvysotskyi (Odesa, May 28-29, 2009). Odesa. OSMU; 2009:189-191. 
16. Struk ZD. Multialternativeness of immunotropic effects of bioactive water Naftussya in conditions of drinking monotherapy [in Ukrainian]. Medical Hydrology and Rehabilitation. 2009;7(2):92-6.

17. Struk $Z D$. Neuroendocrine and clinical accompaniment of various immunotropic effects of bioactive water Naftussya [in Ukrainian]. Medical Hydrology and Rehabilitation. 2009;7(4):51-65.

18. Struk ZD. Variants of immunotropic effects of the course of drinking bioactive water Naftusia in women with chronic endocrine and gynecological pathology In: Proceedings of the X Scientific-Practical Conference (with international participation) «Topical issues of pathology in the event of emergency factors on the body» (Ternopil, October 5-6, 2017). Ternopil, 2017:40-1.

19. Sydoruk NO, Zukow $W$. Differences between the effects of water Naftussya from fields of Truskavets' and Pomyarky on the parameters of the EEG, HRV, immunity and metabolism. Journal of Education, Health and Sport. 2019;9(1):287-93.

20. Balanovs'kyi VP, Popovych IL, Karpynets'SV. About ambivalence-equilibratory character of influence of curative water Naftussya on organism of human [in Ukrainian]. Dopovidi ANU. Mat., pryr., tekhn. Nauky. 1993;3:154-8.

21. Chebanenko OI, Chebanenko LO, Popovych IL. Variety Balneoeffects of Factors Spa Truskavets' and their Forecast [in Ukrainian]. Kyiv: UNESCO-SOCIO; 2012. 496 p.

22. Khaitov RM, Pinegin BV, Istamov KhI. Ecological Immunology [in Russian]. Moskwa: VNIRO; 1995. 219 p.

23. Lapovets' LY, Lutsyk BD. Handbook of Laboratory Immunology [in Ukrainian]. Lviv; 2002. $173 \mathrm{p}$.

24. Douglas SD, Quie PG. Investigation of Phagocytes in Disease. Churchil; 1981. $110 \mathrm{p}$.

25. Popovych IL, Kul'chyns'kyi AB, Gozhenko AI, Zukow W, Kovbasnyuk MM, Korolyshyn TA. Interrelations between changes in parameters of HRV, EEG and phagocytosis at patients with chronic pyelonephritis and cholecystitis. Journal of Education, Health and Sport. 2018;8(2):135-56.

26. Barylyak LG, Malyuchkova RV, Tolstanov OB, Tymochko OB, Hryvnak RF, Uhryn MR. Comparative estimation of informativeness of leucocytary index of adaptation by Garkavi and by Popovych. Medical Hydrology and Rehabilitation. 2013; 11(1):5-20.

27. Petsyukh SV, Petsyukh MS, Kovbasnyuk MM, Barylyak LG, Zukow W. Relationships between Popovych's Adaptation Index and parameters of ongoiging HRV and EEG in patients with chronic pyelonephrite and cholecystite in remission. Journal of Education, Health and Sport. 2016;6(2):99-110.

28. Shannon $C E$. Works on the theory of informatics and cybernetics [transl. From English to Russian]. Moskwa: Inostrannaya literatura; 1963: 329 p.

29. Yushkovs'ka OG. Using information theory to study adaptive responses in the body athletes [in Ukrainian]. Medical Rehabilitation, Kurortology, Physiotherapy. 2001;1(25):40-3.

30. Popovych IL. Information effects of bioactive water Naftyssya in rats: modulation entropic, prevention desynchronizing and limitation of disharmonizing actions water immersion stress for information components of neuro-endocrine-immune system and metabolism, which correlates with gastroprotective effect [in Ukrainian]. Medical Hydrology and Rehabilitation. 2007;5(3):50-70.

31. Popadynets' OO, Gozhenko AI, Zukow W, Popovych IL. Relationships between the entropies of EEG, HRV, immunocytogram and leukocytogram. Journal of Education, Health and Sport. 2019;9(5):651-66.

32. Aldenderfer MS, Blashfield RK. Cluster analysis (Second printing, 1985) [trans. From English in Russian]. In: Factor, Discriminant and Cluster Analysis. Moskva. Finansy I Statistika; 1989:139-214.

33. Klecka WR. Discriminant Analysis [trans. From English to Russian] (Seventh Printing, 1986). In: Factor, Discriminant and Cluster Analysis. Moskva: Finansy I Statistika; 1989:78-138. 


\title{
RESEARCH ARTICLE
}

\section{Predictors of individual immune responses to adaptogens}

\author{
O.I. MEL'NYK', Z.D. STRUK ${ }^{2}$ \\ ${ }^{1}$ Danylo Halyts'kyı̌ National Medical University, L'viv, Ukraine
}

${ }^{2}$ Ukrainian Scientific Research Institute of Medicine for Transport, Odesa, Ukraine

\section{E-mail: omelnyk7@gmail.com}

Introduction. Earlier in the experiments in rats and in clinical observations showed that the immune responses to chronic stress are ambiguous and individual. Adaptogens, in particular balneofactors, are antipodes of stressors. The immune responses to balneotherapy are also ambiguous. Therefore, the purpose of this study is to analyze variants of immune responses to balneofactors of Truskavets' spa as natural adaptogens and to determine the possibility of their prediction. Material and methods. The object of observation were 34 men and 10 women aged 24-70 years old, who came to the Truskavets' spa for the treatment of chronic pyelonephritis combined with cholecystitis in remission. The survey was conducted twice, before and after balneotherapy (drinking bioactive water Naftussya three times a day, ozokerite applications, mineral baths every other day for 7-10 days). Immune status evaluated on a set of I and II levels recommended by the WHO as described in the manuals. In portion of capillary blood we counted up Leukocytogram and calculated two variants of Adaptation Index as well as two variants of Strain Index by IL Popovych. We calculated also the Entropy of Immunocytogram and Leukocytogram. The condition of microbiota is evaluated on the results of sowing of feces and urine. Results. Four variants of the immune responses to adaptogenic balneotherapy have been identified. In $40,9 \%$ of patients, initially normal immune status did not change significantly. In $31,8 \%$, the lower boundary level of immunity is completely normalized. In $22,7 \%$ moderate immunosuppression is reduced, but not up to normal. However, in $4,5 \%$ of people, initially normal level of immunity are transformed into moderate immunosuppression. All four variants of immune responses are virtually unmistakably predicted by a set of 20 predictors, which allows us to make adjustments to balneotherapy in advance. Conclusion. Immune responses to adaptogens are individual and conditioned by a number of predictors.

Key words: Immunity, Chronic Inflammation, Adaptogenic Balneotherapy, Immune Responses. 